\title{
Investigation of Corchorus olitorius mucilage as a potential mucoadhesive agent in developing in situ mucoadhesive nasal gel
}

\author{
Arka Prabha Pal*, Prithviraj Chakraborty \\ Department of Pharmaceutics, Himalayan Pharmacy Institute, Rangpo, India.
}

\section{ARTICLE INFO \\ Received on: 23/06/2019 \\ Accepted on: 23/04/2020 \\ Available online: 05/06/2020}

\section{Key words:}

Mucilage, mucoadhesive,

in situ gel, intranasal

administration.

\begin{abstract}
The present study aimed to formulate a mucoadhesive in situ gel with mucilage extracted from Corchorus olitorius for the intranasal route. Propranolol $\mathrm{HCl}$ used as a model drug. For the comparative study, the mucoadhesive in situ gels were prepared using two different concentration $0.4 \%$ and $0.5 \%$ of C. olitorius mucilage, Carbopol P-934 and hydroxypropyl methylcellulose. The prepared in situ gel was subjected to characterization test, such as $\mathrm{pH}$, appearance, gelation temperature, spreadability, viscosity, mucoadhesive strength, and in vitro study. From the comparative study, $0.5 \%$ mucilage containing in situ gel formulation can be considered as optimum formulation.
\end{abstract}

\section{INTRODUCTION}

An intranasal delivery route is a non-invasive approach that could provide adequate systemic delivery of therapeutic compounds. From the pharmacokinetic point, the intranasal route helps to avoid the first-pass metabolism, which leads to improving bioavailability (Dhuria et al., 2010). Nevertheless, mucociliary clearance becomes a significant disadvantage (Arora et al., 2002). To address this limitation, different dosage form designs have been introduced, such as the use of bioadhesive polymer, adding absorption enhancers, or the use of sophisticated delivery strategy, which may include like nasal gel and powder forms. Ordinarily nasal application of conventional gels or powders are difficult to administer and can be irritative to the mucosal tissue (Upadhyay et al., 2011). To achieve better residence time, a mucoadhesive in situ gelling system appears to be a desirable approach because of its ability to rapid phase transition at the administration site (Singh et al., 2013). These systems are reported to increase the retention time of the specific dosage form within the nasal cavity

${ }^{*}$ Corresponding Author Arka Prabha Pal, Department of Pharmaceutics, Himalayan Pharmacy Institute, Rangpo, India.E-mail: palb846@gmail.com
(Singh et al., 2013). This expedites the drug absorption from this route that leads to improved bioavailability.

The in situ gelling system is a liquid formulation which changes its physicochemical state, liquid/sol to gel under certain physiological conditions. This polymeric system depends upon different stimuli which may include $\mathrm{pH}$, modulated temperature, exchange of solvent, and ionic change (Kaur et al., 2016). In majority, two methods are considered for the development of in situ gel, viz., cold method and hot method. Temperaturesensitive or thermoresponsive in situ gel has been extensively explored compared to other approaches because it has a low adverse effect on local tissues (Wang et al., 2013). The phase transition from a solution to a gel form generally found to be occurred above the lower critical solution temperature, for particular delivery systems, which may be found between $25^{\circ} \mathrm{C}$ and $37^{\circ} \mathrm{C}$.

Numerous methods have been suggested to explain the mucoadhesion mechanism. Mucoadhesion is generally indicated by the contact period (connection duration) between the mucoadhesive polymer and the mucous membrane. Depending on the moisture present in the mucosal layer, the mucoadhesive polymer may tend to attach with the help of its chemical bonds and induce hydrogen and van der Waals bonds with the mucous layer. For better adhesion, mucoadhesive molecules should be capable 
of favouring both mechanical and chemical interaction (Carvalho et al., 2010, Rahamatullah et al., 2011)

This study aims to obtain a mucoadhesive material from a natural source and exploring it in the development of an in situ nasal gel. Mucilage isolated from Corchorus olitorius (jute plant) was explored as a mucoadhesive agent which was compared with two synthetic mucoadhesive polymers - Carbopol and hydroxypropyl methylcellulose (HPMC). Pluronic F-127 was used in this study, to act as a base of the thermosensitive polymeric gel due to its properties as a thermoresponsive gelling agent with no-toxicity, non-irritating, and biocompatibility (Majithiya et al., 2006). To ascertain the quality of the developed formulation of in situ nasal gel, the formulated gels were evaluated for their $\mathrm{pH}$, rheological characteristics, sol-gel transition temperature, adhesion strength, drug content, in vitro release profiles along with the release kinetics.

Propranolol $\mathrm{HCl}$, a synthetic beta-adrenergic receptor blocker, was used as a model drug in this study. This drug is widely recommended in the treatment of angina pectoris, myocardial infarction, cardiac arrhythmia, and hypertension. It has a biological half-life of about 5-6 hours and is subjected to a comprehensive hepatic first-pass effect. The oral bioavailability of propranolol $\mathrm{HCl}$ is reported to be around 26\%-30\% (Gaikwad et al., 2017). The low bioavailability issue can be addressed by delivering this drug through the intranasal route.

Corchorus olitorius, an annual crop, is an erect, herbaceous plant of Malvaceae family, reaching a height of 2.4 $\mathrm{m}$. It is a significant source of natural fibres, mainly in Asian and Latin American countries and as an essential green leafy vegetable in many areas. The cultivation of $C$. olitorius is done in many parts of the world, such as Syria, Lebanon, Palestine, and Egypt, as a potherb and its culinary use go back at least as far as the Ancient Egyptians. It is also cultivated and eaten in the Caribbean and Brazil, in the Middle East and India, Bangladesh, Japan, and China (Loumerem et al., 2016). Different parts of these plants are used as folk medicines. Certain phenolic compounds isolated from $C$. olitorius jute showed great antioxidation, inflammatory inhibition, and cytotoxic activities (Hassan et al., 2019).

Moreover, new flavonol glycosides, isolated from the leaves of $C$. olitorius; corchorusides A and B exhibited $\alpha$-glucosidase inhibitor activity. Corchorus olitorius exhibited diverse biological activities, including antioxidant, antitumor, hypoglycemia, antimicrobial, anti-inflammatory, analgesic, antiobesity, gastroprotective, and wound healing effects (Hassan et al., 2019).

\section{MATERIALS}

Propranolol $\mathrm{HCl}$ was obtained from Yarrow Chem, Mumbai. Pluronic F-127 was purchased from Sigma-Aldrich, India. Carbopol P-934, HPMC were purchased from SDFCL, Mumbai. All the other chemicals and ingredients were used in the study were of analytical grade.

\section{METHODS}

\section{Extraction of the mucoadhesive agent from plant source}

Corchorus olitorius leaves were collected from the local vendor and washed thoroughly. Then, the leaves were cut into small pieces and dried under shaded conditions. Then, three times the volume of distilled water was added to the leaves and soaked for 6 hours and then boiled for 1 hour and left undisturbed for an hour. The liquid extract was separated from the marc by passing through a multi-layer muslin cloth without squeezing. The filtrate was kept undisturbed for some time and concentrated by heating on a water bath at $60^{\circ} \mathrm{C}$. After cooling, the extract was added to three times its volume of acetone and stirred. Separated masses were collected and dried at $60^{\circ} \mathrm{C}$ in a hot air oven. Dried masses were powdered and stored in desiccators (Assi et al., 2017; Azubuike et al., 2017).

\section{Phytochemical characterization of mucilage}

The extracted mass was treated with ruthenium red solution to determine the presence of mucilage. The mucilage was treated with $\alpha$-naphthol and concentrated sulphuric acid for carbohydrates. Fehling's solution A and B was used for detecting the presence of reducing sugar in extracted mucilage. The mucilage was again treated with ferric chloride and lead acetate solution for the detection of tannins. The extract was also treated with $2 \%$ copper sulphate solution and ethanol, along with potassium hydroxide pellets for the detection of proteins (Raaman, 2006).

\section{Determination of $\mathbf{p H}$}

$\mathrm{pH}$ of $1 \% \mathrm{w} / \mathrm{v}$ aqueous solutions of the mucilage was measured by digital $\mathrm{pH}$ meter (Multipara, MP-5).

\section{Study of swollen volume}

Aliquot of $300 \mathrm{mg}$ of the mucilage powder was put in 6 $\mathrm{ml}$ of water in a measuring cylinder for 24 hours. Swollen volume was recorded and determined with the following equation:

Swollen Volume $=V_{2}-V_{1}$

where, $V_{1}$ is the initial volume and $V_{2}$ volume is the final volume.

\section{Loss on drying}

The powdered mucilage sample was taken in a petri dish and dried in a hot air oven at $110^{\circ} \mathrm{C}$ until a constant weight was obtained.

Loss on drying $(\%)=\left(W_{1}-W_{2}\right) / W_{1}^{*} 100$

where, $W_{1}=$ Original weight of sample $(\mathrm{mg}) ; W_{2}=$ Constant weight of the sample attained (mg).

\section{Drug-polymer interaction study}

Fourier-transform infrared spectroscopy (FT-IR) study was done to identify any possible drug-polymer interaction. IR spectrum of pure of Propranolol $\mathrm{HCl}$ and extracted mucilage were analyzed in Attenuated total reflectance (ATR) -FT-IR Spectrophotometer (Agilent Technology, CDR-630). Also, a physical mixture of the drug:mucilage $(1: 1)$ and drug:polymer (1:1) was made by the trituration process, in a mortar and pestle, also analyzed. The mixtures of drug and polymer samples were kept for 15 days before taking the IR spectrum. The samples were scanned from 500 to $4,000 \mathrm{~cm}^{-1}$ wave number.

\section{Preparation of in situ gels}

In situ gels were produced based on the formula in Table 1, using the cold method. (Basu and Bandyopadhyay, 2010; 
Table 1. Formulation codes.

\begin{tabular}{|c|c|c|c|c|c|c|c|}
\hline Formulation code & F0 & F1 & F2 & F3 & F4 & F5 & F6 \\
\hline Propranolol HCL & - & $4.8 \mathrm{mg} / \mathrm{ml}$ & $4.8 \mathrm{mg} / \mathrm{ml}$ & $4.8 \mathrm{mg} / \mathrm{ml}$ & $4.8 \mathrm{mg} / \mathrm{ml}$ & $4.8 \mathrm{mg} / \mathrm{ml}$ & $4.8 \mathrm{mg} / \mathrm{ml}$ \\
\hline Pluronic F127 (\%w/v) & $18 \%$ & $18 \%$ & $18 \%$ & $18 \%$ & $18 \%$ & $18 \%$ & $18 \%$ \\
\hline Carbopol 934P (\% w/v) & - & $0.5 \%$ & $0.4 \%$ & - & - & - & - \\
\hline $\operatorname{COM}(\% \mathrm{w} / \mathrm{v})$ & - & - & - & $0.5 \%$ & $0.4 \%$ & - & - \\
\hline HPMC (\% w/v) & - & - & - & - & - & $0.4 \%$ & $0.5 \%$ \\
\hline $\begin{array}{l}\text { Propylene Glycol } \\
(\% \mathrm{w} / \mathrm{v})\end{array}$ & $1 \%$ & $1 \%$ & $1 \%$ & $1 \%$ & $1 \%$ & $1 \%$ & $1 \%$ \\
\hline $\begin{array}{l}\text { Benzalkonium } \\
\text { Chloride }(\% \mathrm{w} / \mathrm{v})\end{array}$ & $0.01 \%$ & $0.01 \%$ & $0.01 \%$ & $0.01 \%$ & $0.01 \%$ & $0.01 \%$ & $0.01 \%$ \\
\hline
\end{tabular}

Schmolka, 1972). Briefly, an 18\% w/v Pluronic F-127 was weighed and dissolved in a solution of propylene glycol:water and then the mucoadhesive agent (synthetic or natural) was added to it with thorough mixing using stirrer at $200 \mathrm{rpm}$ Propranolol $\mathrm{HCl}$ was added to the homogenous solution with continuous stirring and was kept at $4{ }^{\circ} \mathrm{C}$ overnight. Formulation codes are depicted in Table 1.

\section{Appearance}

The appearance of the formulations was determined by visual inspection.

\section{pH of formulation}

The $\mathrm{pH}$ of all formulations was measured using a digital $\mathrm{pH}$ meter, and the $\mathrm{pH}$ meter was calibrated with buffers of $\mathrm{pH} 4$ and $\mathrm{pH} 7$ before the measurements (Jagdale et al., 2016).

\section{Measurement of gelation temperature and time}

The sol-gel transition temperatures of the formulations were determined using the technique described by Altuntaş and Yener (2017). Briefly, a pre-weighted amount of formulation in solution form was transferred into a glass beaker containing a magnetic bar that was allowed to rotate within, with the help of a magnetic stirrer (Tarsons Spinot Digital, MC 02). The beaker was heated at an increasing rate of $1^{\circ} \mathrm{C}$ per minute, with constant stirring at $80 \mathrm{rpm}$. The temperature at which the magnetic bar stopped its rotation was considered as the gelation temperature and time taken for converting the solution into gel was recorded.

\section{Spreadability test}

To determine the spreadability of in situ gel, approximately $0.5 \mathrm{~g}$ of the gel was placed at the centre of the glass plate $(15 \mathrm{~cm} \times 15 \mathrm{~cm})$. One glass plate was covered with another glass plate. Next, the weight of $300 \mathrm{~g}$ was applied on the upper side of the plate; as a result, the gel was spread out in between the two plates. After 5 minutes, the weight was removed, and the diameter of the spread area $(\mathrm{cm})$ was measured (Chaudhary and Verma, 2014). The study was done in three replicates.

\section{Viscosity studies}

The viscosity was measured at $37^{\circ} \mathrm{C}$ using Brookfield viscometer using spindle number 64 at $100 \mathrm{rpm}$.

\section{Drug content estimation}

One milliliter formulation was taken in a $10 \mathrm{ml}$ volumetric flask and diluted with distilled water. The diluted solution was filtered, and $1 \mathrm{ml}$ of filtered solution was again diluted to $10 \mathrm{ml}$ with distilled water. Drug content was estimated by measuring the absorbance of the above solution at $289 \mathrm{~nm}$ using a UV visible spectrophotometer (Shimadzu 1800) (Jagdale et al., 2016). The \% drug content was calculated using the following equation

$$
\mathrm{X}=\mathrm{Y}-\mathrm{C} / \mathrm{M}
$$

where $X$ is conc. in $\mu \mathrm{g} / \mathrm{ml}, \mathrm{Y}$ is the absorbance of the solution, $\mathrm{C}$ is the intercept of the standard curve, and $\mathrm{M}$ is the slope of the standard curve, which was plotted between the absorbance of known concentration of drug dissolved distilled water. The absorbance was measured at $289 \mathrm{~nm}$ using a UV visible spectrophotometer (Shimadzu,1800).

$$
\% \text { Drug Content }=\frac{\text { Concentration of drug in sample solution }}{\text { equivalent concentration of drug taken }} * 100
$$

\section{In vitro drug release study}

Franz diffusion cells were used for the study with a dialysis membrane. Dialysis membrane (molecular weight 12,00014,000 Dalton.) was placed in between the donor and the receptor compartment. Aliquots of $1 \mathrm{ml}$ of the formulation containing drug equivalent to $4.8 \mathrm{mg}$ were applied on the surface of the membrane. It was in contact with the receptor compartment containing $100 \mathrm{ml}$ of phosphate buffer $\mathrm{pH}$ 6.4. The cell was agitated by a magnetic stirrer at $60 \mathrm{rpm}$ and maintained at $37^{\circ} \mathrm{C}$. Aliquots of $1 \mathrm{ml}$ of diffusional media were withdrawn at specific intervals and were replaced with an equal volume of fresh phosphate buffer $\mathrm{pH} 6.4$. The absorbance of the withdrawn media was measured at $289 \mathrm{~nm}$.

\section{Drug release kinetic study}

The drug release mechanism from the formulation, drug release data obtained from in vitro drug release studies for the formulations were analyzed by fitting the data into different kinetic models (Altuntaş and Yener, 2017).

\section{Texture profile analysis}

Texture profile analysis of all formulations was evaluated by TA-XT2 texture analyser (Stable Microsystems) equipped with a $5 \mathrm{~kg}$ load cell. Formulations were initially transferred into a jacketed glass vial $(20 \mathrm{ml})$ at $37^{\circ} \mathrm{C}$. An analytical probe was inserted into each formulation to a defined depth of $15 \mathrm{~mm}$ and at a defined rate of $2 \mathrm{~mm} / \mathrm{seconds}$, allowing a period of the 30 seconds between the end of the first and the beginning of the second compression. The probe holding the mucosa was lowered onto the surface of the gel with a constant speed of $0.5 \mathrm{~mm} / \mathrm{seconds}$ until in 
contact with the gel surface, and a contact force of $4.0 \mathrm{~g}$ was then applied for 2 minutes. From the time curve, the mucoadhesive property of the gel was determined (Baloglu et al., 2011).

\section{RESULTS AND DISCUSSION}

\section{Phytochemical characterization of mucilage}

Chemical identification of extracted mass isolated from $C$. olitorius (jute plant) leaves was performed, as shown in Table 2. The treatment of the extracted mass with ruthenium red solution confirmed its mucilaginous property. The mucilage was treated with $\alpha$-naphthol and concentrated sulphuric acid, which gives a reddish-pink colour ring, which revealed that it consists of carbohydrates. The mucilage, when treated with ferric chloride solution for detection of tannins, showed dark green colour indicating the presence of tannin. A white precipitate was observed when the mucilage was treated with lead acetate solution, which also confirms the presence of tannins. By treating the mucilage with Fehling's solution A and B, the mucilage solution gave a brick-red precipitate after heating, which indicates the presence of reducing sugars. Furthermore, the mucilage when tested with the Biuret test, the result indicates the absence of proteins (Raaman, 2006).

\section{Determination of ${ }_{\mathrm{p}} \mathbf{H}$}

$\mathrm{pH}$ of $C$. olitorius (jute plant) mucilage was found to be $6.105 \pm 0.369(n=3)$, which is within the $\mathrm{pH}$ range of nasal route, that is $5.5-7.5$.

\section{Study of swollen volume}

Swellability data is presented in Table 3. Corchorus olitorius mucilage swellability was found to be higher than formulation containing HPMC but lower than the formulation containing Carbopol as a mucoadhesive material. For optimum adhesion, swellability is a valuable property.

\section{Loss on drying}

A $19.5 \%$ loss in weight was recorded on drying.

\section{Drug-polymer interaction study}

Drug-polymer interaction was determined by comparing the IR spectra of the pure drug along with the drug-polymer

Table 2. Chemical identification.

\begin{tabular}{lc}
\hline Name & Presence \\
\hline Carbohydrates & ++ \\
Tannins & ++ \\
Proteins & -- \\
Reducing sugars & ++ \\
Mucilage & ++ \\
\hline
\end{tabular}

Table 3. Result of swollen volume.

\begin{tabular}{lc}
\hline Mucoadhesive agent & Swollen volume $(\mathbf{c m} / \mathbf{m g})$ \\
\hline Corchorus (jute plant) mucilage & $1.8 \pm 0.16$ \\
HPMC & $1.3 \pm 0.34$ \\
Carbopol 934 & $2.9 \pm 0.11$ \\
\hline
\end{tabular}

All values were expressed as the mean $\pm \mathrm{SD}, n=3$. mixture. As shown in Figure 1A, Propranolol $\mathrm{HCl}$ gives the peaks in the IR spectrum at $3,271.07 \mathrm{~cm}^{-1}$ due to the hydroxyl group $(\mathrm{O}-\mathrm{H})$, at $2,802.637 \mathrm{~cm}^{-1}$ due to the presence of an amine group $(\mathrm{N}-\mathrm{H})$, at $1,265.158 \mathrm{~cm}^{-1}$ due to aryl alkyl ether group (R-O-R'). At $795.795 \mathrm{~cm}^{-1}$ due to a-substituted naphthalene group. Figure 1B shows the IR Spectrum of $C$. olitorius (jute plant) mucilage. Figure $1 \mathrm{C}-\mathrm{E}$ revealed the presence of peaks at $3,271.07,1,265.158,2,802.637$, and $795.795 \mathrm{~cm}^{-1}$ that indicated that the frequencies of functional groups of pure drugs did not change in the mixture containing different polymers. This result shows that there was no primary interaction between the drug and the polymer.

\section{Preparation of in situ gels}

Prepared in situ gels formulations are coded as provided in Table 1. Pluronic F-127 was used as a base thermosensitive polymeric gel. The concentration for the Pluronic F-127 was kept constant at $18 \% \mathrm{w} / \mathrm{v}$ as this concentration showed reversal thermal gelation, transforming from a liquid into a semisolid gel in 1-2 minutes at the characteristic sol-gel transition temperatures (Nie et al., 2011). Corchorus olitorius mucilage was compared to Carbopol P-934 and HPMC as a mucoadhesive agent. Considering the different concentrations of the mucoadhesive polymers, six formulations were made. Compared to Carbopol P-934 and HPMC based in situ gel, the $C$. olitorius mucilage-based formulation F3 (Fig. 2) had a gelation temperature of $28^{\circ} \mathrm{C}$, which was acceptable for nasal application as it was nearer to the nasal physiological temperature range $29^{\circ} \mathrm{C}-34^{\circ} \mathrm{C}$ with least gelation time (Wang et al., 2017)

\section{Appearance}

The mucilage based formulations were coloured turbid solutions (Table 4).

\section{pH of formulation}

The mean $\mathrm{pH}$ values of all the formulations (Table 5) from F1 to F6 were recorded in the range of 5.2 to 6.23 , which is nearer to average baseline human nasal $\mathrm{pH}$ which was reported to be around 6.3 (Washington et al., 2000).

\section{Measurement of gelation temperature and time}

Gelation temperature and time range were shown in Table 6. Gelation temperature for all the formulations was found in the range of $26^{\circ} \mathrm{C}-32^{\circ} \mathrm{C}$ and time range 58 seconds to 2 minites. It was observed that depending upon the concentration of mucoadhesive polymer material, an alteration in the gelation temperature occurs in the formulations.

\section{Spreadability test}

The spreadability test result was documented in Table 7. The mean spreadability for all the formulations from F1 to F6 was recorded between the range of $8.3-9.9 \mathrm{~cm}$. From the study, it was noticed that spreadability was dependent upon the viscosity range for all the formulations.

\section{Viscosity studies}

Viscosity of all the formulations from F1 to F6 is between the range of 4,010 and 5,000 cps shown in Table 8 . The 

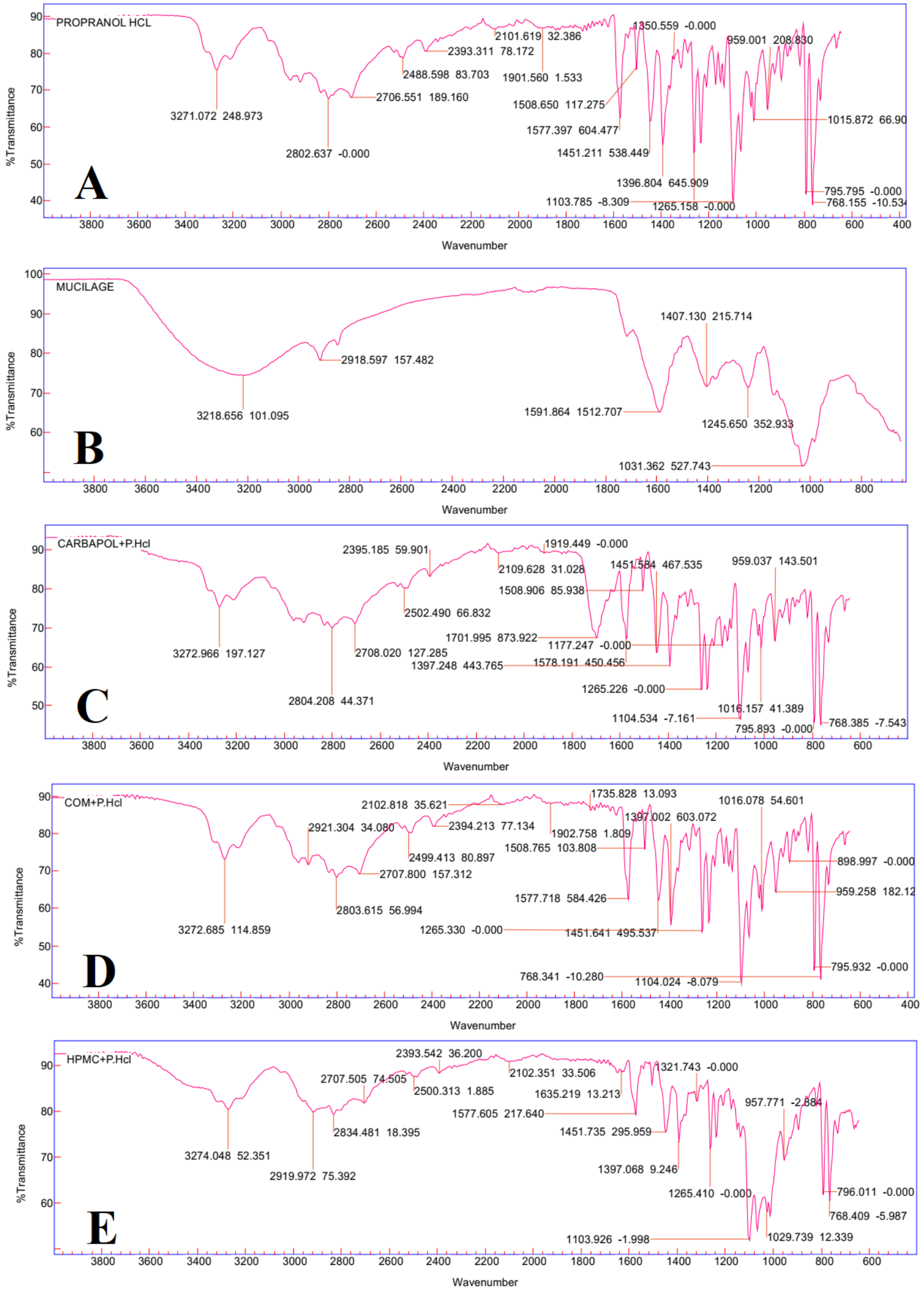

Figure 1. ATR FT-IR analysis of (A) Pure drug Propranolol HCL(P.HCL), (B) C. olitorius Mucilage (COM), (C) Carbopol +P.HCL, (D) COM+P.HCL, (E) HPMC+P.HCL. 
Sol Form

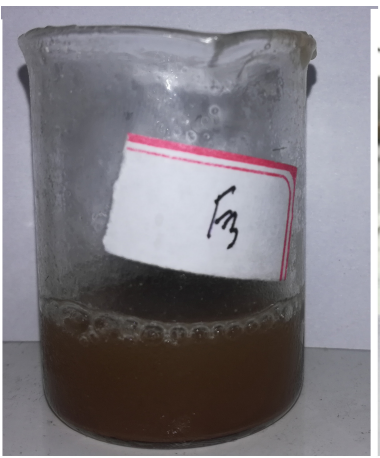

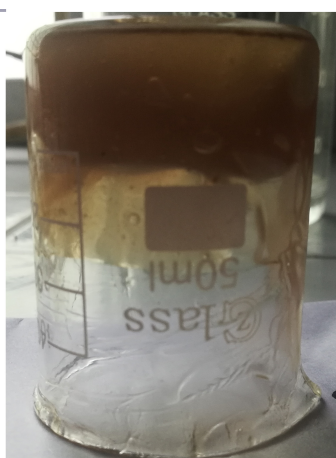

Gel Form
Figure 2. Mucilage based in situ gel.

Table 4. Appearance of in situ gels.

\begin{tabular}{ccl}
\hline Sl. No. & Formulation code & Appearance \\
\hline 1 & F0 & Transparent solution \\
2 & F1 & Turbid and viscous solution \\
3 & F2 & Turbid and viscous solution \\
4 & F3 & Coloured turbid solution \\
5 & F4 & Coloured turbid solution \\
6 & F5 & Transparent and viscous solution \\
7 & F6 & Transparent and viscous solution \\
\hline
\end{tabular}

Table 5. pH of in situ gels.

\begin{tabular}{ccc}
\hline Sl. No. & Formulation code & $\mathbf{p H}$ \\
\hline 1 & F1 & $5.279 \pm 0.235$ \\
2 & F2 & $5.245 \pm 0.536$ \\
3 & F3 & $6.23 \pm 0.285$ \\
4 & F4 & $6.102 \pm 0.196$ \\
5 & F5 & $5.901 \pm 1.023$ \\
6 & F6 & $5.703 \pm 0.690$ \\
\hline
\end{tabular}

All values were expressed as the mean $\pm \mathrm{SD}, n=3$.

Table 6. Gelation temperature and time.

\begin{tabular}{cccl}
\hline Sl. No. & Formulation code & Gelation temp. & Time \\
\hline 1 & F0 & $32^{\circ} \mathrm{C}$ & 2 minutes 19 seconds \\
2 & F1 & $30-31^{\circ} \mathrm{C}$ & 2 minutes \\
3 & F2 & $29^{\circ} \mathrm{C}$ & 1 minute 50 seconds -2 minutes \\
4 & F3 & $28^{\circ} \mathrm{C}$ & 58 seconds -1 minute \\
5 & F4 & $28^{\circ} \mathrm{C}$ & 1 minute 6 seconds \\
6 & F5 & $28^{\circ} \mathrm{C}$ & 1 minute 10 seconds \\
7 & F6 & $26^{\circ} \mathrm{C}-27^{\circ} \mathrm{C}$ & 1 minute 11 seconds \\
\hline
\end{tabular}

study result showed that with an increase in the concentration of the adhesive polymer, the viscosity of the formulations also increased.

\section{Drug content estimation}

Drug content was found in the range of $93.7 \%$ to $94 \%$ (Table 9).
Table 7. Spreadability of in situ gel.

\begin{tabular}{cc}
\hline Formulations & Spreadability $(\mathbf{c m})$ \\
\hline F1 & $8.3 \mathrm{~cm} \pm 0.20$ \\
F2 & $8.5 \mathrm{~cm} \pm 0.23$ \\
F3 & $9.0 \mathrm{~cm} \pm 0.50$ \\
F4 & $9.9 \mathrm{~cm} \pm 0.50$ \\
F5 & $9.2 \mathrm{~cm} \pm 0.25$ \\
F6 & $8.7 \mathrm{~cm} \pm 0.25$ \\
\hline
\end{tabular}

All values were expressed as the mean $\pm \mathrm{SD}, n=3$.

Table 8. Viscosity of in situ gel.

\begin{tabular}{cc}
\hline Formulation code & Viscosity (100rpm) \\
\hline F1 & $5,000 \mathrm{cps}$ \\
F2 & $4,630 \mathrm{cps}$ \\
F3 & $4,801 \mathrm{cps}$ \\
F4 & $4,010 \mathrm{cps}$ \\
F5 & $4,500 \mathrm{cps}$ \\
F6 & $4,801 \mathrm{cps}$ \\
\hline
\end{tabular}

Table 9. Drug content of in situ gels.

\begin{tabular}{cc}
\hline Formulation code & Drug contain (\%) \\
\hline F1 & $94.0 \pm 0.59$ \\
F2 & $94.0 \pm 0.89$ \\
F3 & $94.0 \pm 0.67$ \\
F4 & $93.7 \pm 0.91$ \\
F5 & $95.8 \pm 0.35$ \\
F6 & $93.7 \pm 0.46$ \\
\hline
\end{tabular}

All values were expressed as the mean $\pm \mathrm{SD}, n=3$.

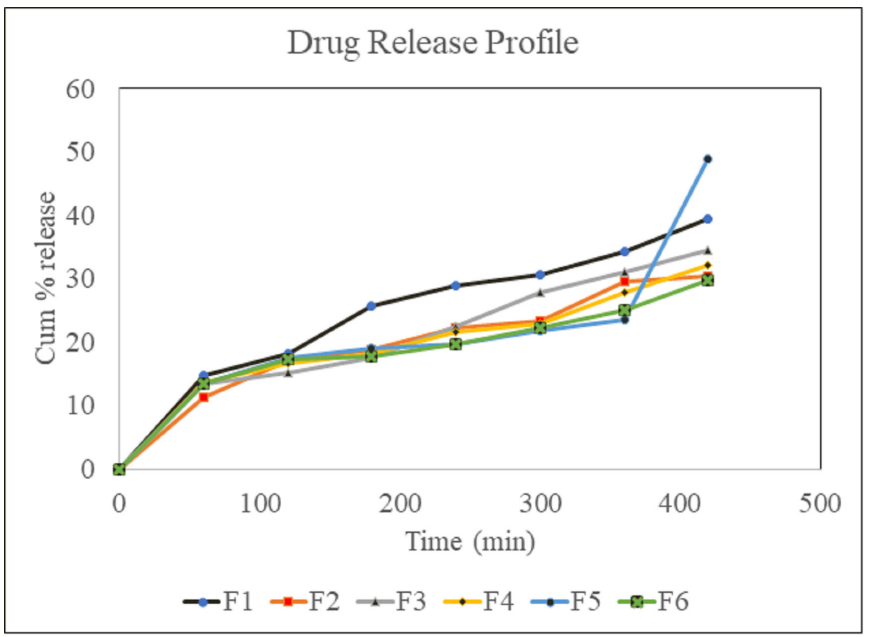

Figure 3. In-vitro drug release profile of different formulations.

\section{In vitro drug release study}

From the study, it was observed that polymer concentration affects the release rate (Fig. 3). The in vitro diffusion study shows that formulations F1, F3, and F5 had 39.55\%, 35.19\%, 
and $48.95 \%$ release, respectively, after 7 hours. The release pattern from HPMC-based in situ gels showed that with the increase in the concentration of the adhesive polymer, drug release was reduced, but Carbopol and mucilage-based gels were exceptional. The in vitro drug release profiles of all the formulations are shown in Table 10.

\section{Drug release kinetic study}

The release kinetic profile for formulations is documented in Figure 4. On comparing the regression coefficient values, after fitting the in vitro release data, to different kinetic models, the $R^{2}$ value of different kinetic models was recorded in Table 11. The release data were found to be following first-order kinetics with best fitted to Korsmeyer-Peppas model. On comparing the $n$ value of the Korsmeyer-Peppas model, it was found to be in between
0.47 and 0.51 , indicating an anomalous or non-Fickian release of drug from the formulations.

\section{Texture profile analysis}

From the mucoadhesive test, it was found that the mucoadhesive strength increase with the increase in the concentration of the mucoadhesive agent. Compared to the Carbopol and HPMC-based gels, the mucilage incorporated gel showed the better adhesive property. Texture analysis for mucoadhesion was done and the detachment force of Carbopol, mucilage and HPMC was found to be $4.1,5.4$, and $4.8 \mathrm{~g}$, respectively. The study also shows that the residence time of mucilage-based formulation F3 (Fig. 5) gives better results compared to the Carbopol and HPMC-based in situ gel.

Table 10. In vitro drug release profile.

\begin{tabular}{|c|c|c|c|c|c|c|}
\hline Time (minute) & F1 & F2 & F3 & F4 & F5 & F6 \\
\hline 0 & 0 & 0 & 0 & 0 & 0 & 0 \\
\hline 60 & 14.83279396 & 11.23892 & 13.34951 & 13.64617 & 13.5383 & 13.34951 \\
\hline 120 & 18.25782093 & 17.05678 & 15.42638 & 16.61597 & 17.47681 & 17.31005 \\
\hline 180 & 25.76523732 & 18.75271 & 17.94203 & 18.28939 & 19.06176 & 17.70184 \\
\hline 240 & 28.9349137 & 22.16188 & 22.95405 & 21.55827 & 19.63171 & 19.60808 \\
\hline 300 & 30.7220658 & 23.3904 & 28.44729 & 22.91765 & 21.90802 & 22.28434 \\
\hline 360 & 34.31675836 & 29.64021 & 31.68403 & 27.79824 & 23.46363 & 24.97554 \\
\hline 420 & 39.5661219 & 30.50356 & 35.19913 & 32.10257 & 48.95253 & 29.77741 \\
\hline
\end{tabular}
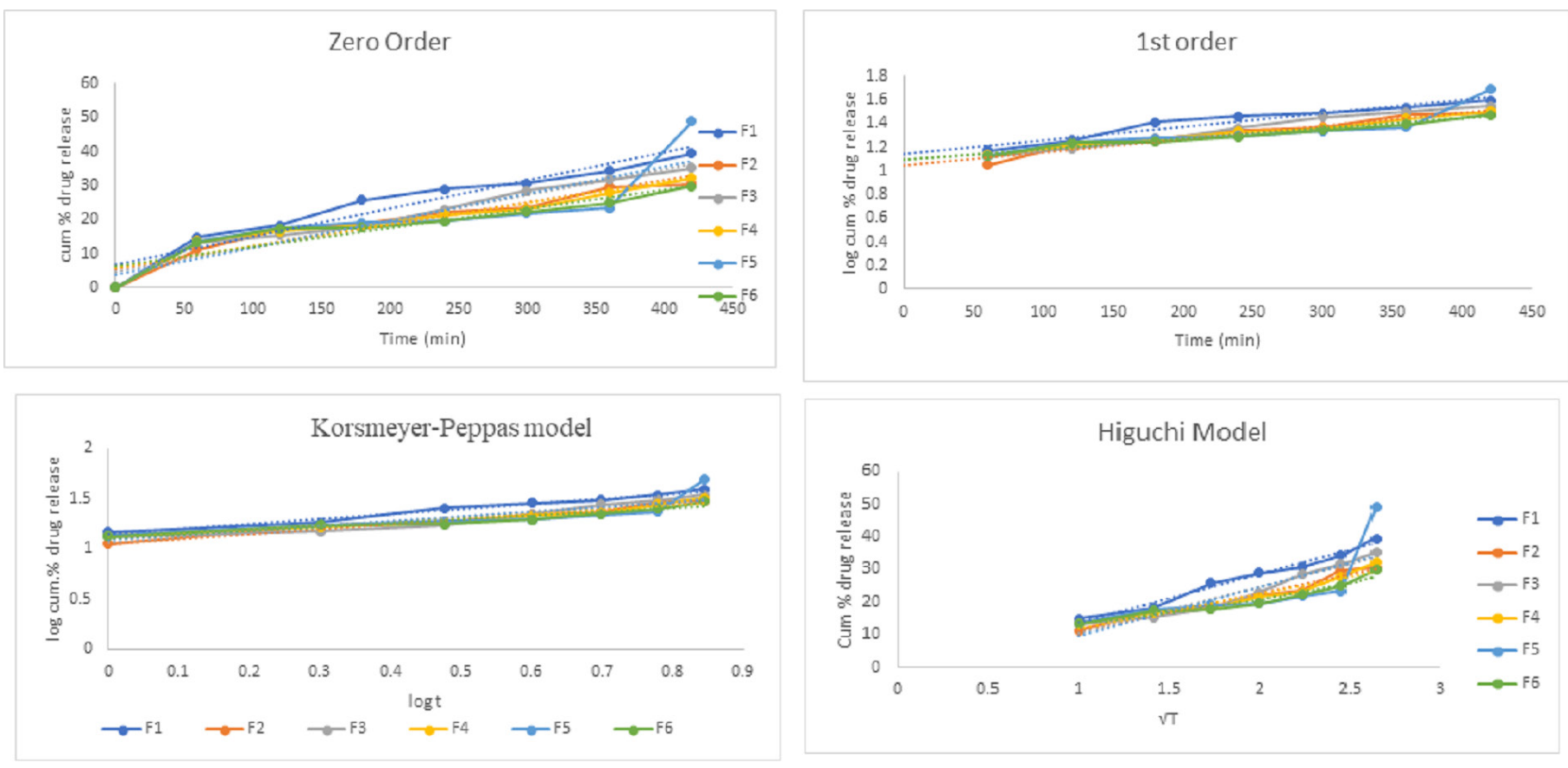

Figure 4. Release kinetic profile of different formulations. 
Table 11. Release kinetic data.

\begin{tabular}{|c|c|c|c|c|c|}
\hline \multirow{2}{*}{ Formulation } & \multirow{2}{*}{$\frac{\text { Zero order }}{R^{2}}$} & \multirow{2}{*}{$\frac{\text { First order }}{R^{2}}$} & \multicolumn{2}{|c|}{ Korsmeyer-Peppas } & \multirow{2}{*}{$\frac{\text { Higuchi }}{R^{2}}$} \\
\hline & & & $R^{2}$ & $n$ & \\
\hline $\mathrm{F} 1$ & 0.9197 & 0.9362 & 0.9763 & 0.50 & 0.978 \\
\hline $\mathrm{F} 2$ & 0.9147 & 0.9278 & 0.9756 & 0.499 & 0.9661 \\
\hline F3 & 0.9312 & 0.9855 & 0.9462 & 0.51 & 0.9175 \\
\hline F4 & 0.9008 & 0.9899 & 0.928 & 0.41 & 0.9277 \\
\hline F5 & 0.7548 & 0.7784 & 0.6496 & 0.47 & 0.5597 \\
\hline F6 & 0.8624 & 0.9685 & 0.9159 & 0.36 & 0.9134 \\
\hline
\end{tabular}

\section{TA Express}

Keycode: 0016949009110450

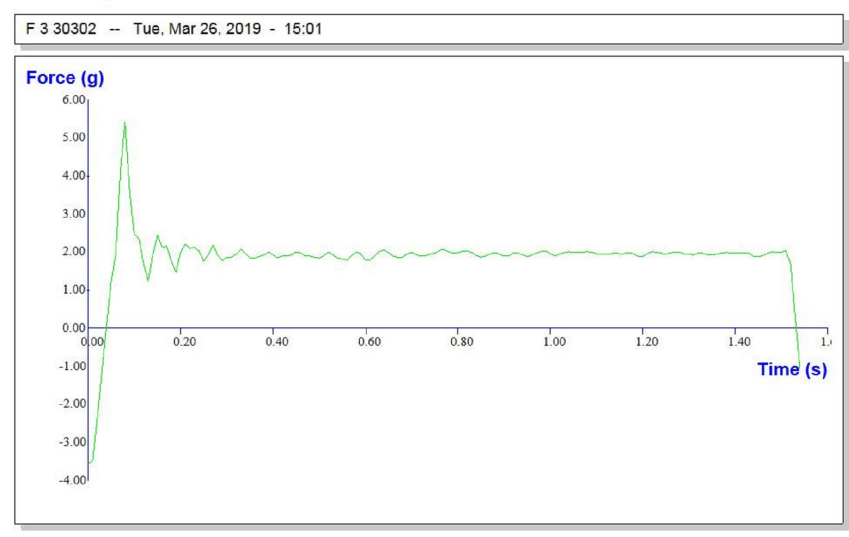

Figure 5. Texture analysis profile of formulation F3.

\section{CONCLUSION}

The objective of the proposed work was to develop an in situ gelling systems employing a natural mucoadhesive agent. To achieve this objective, the mucilage was extracted from the plant source, $C$. olitorius (jute plant). The mucilage extracted from $C$. olitorius showed a hopeful mucoadhesive property when compared to synthetic polymers, such as Carbopol P-934, HPMC which are commercially widely used in the preparation of nasal gels. The comparative study showed that mucilage containing gel results more or less similar to the synthetic polymer-based gels with the better mucoadhesive property. From this effect, two different formulations containing different concentration of mucilage obtained from $C$. olitorius leaves was developed and it can be concluded that among two mucilage-based formulation, F3 $(0.5 \% \mathrm{w} / \mathrm{v}$ mucilage of $C$. olitorius $)$ is considered as an optimum formulation. The in situ gel which is being prepared from natural mucilage might provide an economical dosage form for the intranasal delivery route for the upcoming future.

\section{ACKNOWLEDGMENT}

The authors would like to thank the Management, Himalayan Pharmacy Institute, for providing all the facilities to carry out the work. The authors also thank GIPS, Guwahati for providing the Texture Analysis Facility.

\section{AUTHOR'S CONTRIBUTIONS}

All the authors contributed equally.

\section{FINANCIAL SUPPORT}

None.

\section{CONFLICTS OF INTEREST}

The authors declare no conflict of interest.

\section{REFERENCES}

Altuntaş E, Yener G. Formulation and evaluation of thermoreversible in situ nasal gels containing mometasone furoate for allergic rhinitis. AAPS PharmSciTech, 2017; 18(7):2673-82.

Arora P, Sharma S, Garg S. Permeability issues in nasal drug delivery. Drug Discov Today, 2002; 7(18):967-75.

Assi OY, Sidibé D, Kouakou P, Deigna-Mockey V, Konan YN, Coulibaly A, Biego HG. Characterization of the mucilages of four food plants, Abelmoschus esculentus, Beilschmiedia mannii, Corchorus olitorius, and Irvingia gabonensis, from Côte d'lvoire. Biotech J Inter, 2017; 19(2):1-10.

Azubuike CP, Alfa MA, Oseni BA. Characterization and evaluation of the suspending Potentials of Corchorus olitorius mucilage in pharmaceutical suspensions. Trop J Nat Prod Res, 2017; 1(1):39-46.

Basu S, Bandyopadhyay AK. Development and characterization of mucoadhesive in situ nasal gel of midazolam prepared with Ficus carica mucilage. AAPS PharmSciTech, 2010; 11(3):1223-31.

Baloglu E, Karavana SY, Senyigit ZA, Hilmioglu-Polat S, Metin DY, Zekioglu O, Guneri T, Jones DS. In-situ gel formulations of econazole nitrate: preparation and in-vitro and in-vivo evaluation. J Pharm Pharmacol, 2011; 63(10):1274-82.

Carvalho FC, Bruschi ML, Evangelista RC, Gremião MP. Mucoadhesive drug delivery systems. Braz J Pharm Sci, 2010; 46(1):1-7.

Chaudhary B, Verma S. Preparation and evaluation of novel in situ gels containing acyclovir for the treatment of oral herpes simplex virus infections. Sci World J, 2014; 2014:280928; doi: $10.1155 / 2014 / 280928$

Dhuria SV, Hanson LR, Frey II WH. Intranasal delivery to the central nervous system: mechanisms and experimental considerations. J Pharm Sci, 2010; 99(4):1654-73.

Gaikwad D, Kurane P, Mali D, Jadhav N. Development of particulate mucoadhesive gel for intranasal delivery. Asian J Pharm Clin Res, 2017; 10(5):222-7.

Hassan AZ, Mekhael MKG, Hanna AG, Simon A, Toth G, Duddeck H. Phytochemical investigation of Corchorus olitorius and Corchorus capsularis (Family Tiliaceae) that grow in Egypt. Egypt Pharm J, 2019; 18:123-34.

Jagdale S, Shewale N, Kuchekar BS. Optimization of thermoreversible in situ nasal gel of timolol maleate. Scientifica. 2016.

Kaur P, Garg T, Rath G, Goyal AK. In situ nasal gel drug delivery: a novel approach for brain targeting through the mucosal membrane. Artif Cells Nanomed Biotechnol, 2016; 44(4):1167-76.

Loumerem M, Alercia, A. Descriptors for jute (Corchorus olitorius L.). Genet Resour Crop Evol, 2016; 63(7):1103-11.

Majithiya RJ, Ghosh PK, Umrethia ML, Murthy RS. Thermoreversible-mucoadhesive gel for nasal delivery of sumatriptan. AAPS PharmSciTech, 2006; 7(3):E80-6. 
Nie S, Hsiao WLW, Pan W, Yang Z. Thermoreversible Pluronic $^{\circledR}$ F127-based hydrogel containing liposomes for the controlled delivery of paclitaxel: in vitro drug release, cell cytotoxicity, and uptake studies. Int J Nanomed, 2011; 6:151-66.

Raaman N. Phytochemical techniques. New India Publishing, New Delhi, India, 2006.

Rahamatullah STR, Garland MJ, Woolfson AD, Donnelly RF. Mucoadhesive drug delivery systems. J Pharm Bioallied Sci, 2011; 3(1):89.

Schmolka IR. Artificial skin I. Preparation and properties of pluronic F-127 gels for treatment of burns. J Biomed Mater Res, 1972; 6(6):571-82.

Singh RM, Kumar A, Pathak K. Thermally triggered mucoadhesive in situ gel of loratadine: $\beta$-cyclodextrin complex for nasal delivery. AAPS PharmSciTech, 2013; 14(1):412-24.

Upadhyay S, Parikh A, Joshi P, Upadhyay UM, Chotai NP. Intranasal drug delivery system-A glimpse to become maestro. J App Pharm Sci, 2011; 1(03):34-44.

Wang X, Liu G, Ma J, Guo S, Gao L, Jia Y, Li X, Zhang Q. In situ gel-forming system: an attractive alternative for nasal drug delivery. Crit Rev Ther Drug Carrier Syst, 2013; 30(5).
Wang Y, Jiang S, Wang H, Bie H. A mucoadhesive, thermoreversible in situ nasal gel of geniposide for neurodegenerative diseases. PLoS One, 2017; 12(12):e0189478. doi:10.1371/ journal. pone. 0189478

Washington N, Steele RJ, Jackson SJ, Bush D, Mason J, Gill DA, Pitt K, Rawlins DA. Determination of baseline human nasal $\mathrm{pH}$ and the effect of intranasally administered buffers. Int J Pharm, 2000; 198:139-46.

How to cite this article:

Pal AP, Chakraborty P. Investigation of Corchorus olitorius mucilage as a potential mucoadhesive agent in developing in situ mucoadhesive nasal gel. J Appl Pharm Sci, 2020; 10(06):090-098. 